\title{
Some Properties of Proteins in Taro Corms and
}

\section{Cassava Roots}

\author{
Ikuzo Uritani*, Wakako TakeUchi ${ }^{*}$, Yoshiko KoJIMA* , Miho SaSaKI* , \\ Shuko Naito*, Kazuko NaGata ${ }^{*}$ and Virgilio V. GarCIA ${ }^{* *}$ \\ *Faculty of Domestic Science, Nagoya Women's University, \\ 3-40, Shioji-cho, Mizuho-ku, Nagoya 467 \\ ** Institute of Food Science and Technology, the University \\ of the Philippines at Los Baños, College, Laguna \\ 4031, Philippines
}

The proteins in the crystalline part (lower part) of crystalline taro (a kind of physiologically-deteriorated taro), occurring in the childcorms of Colocasia esculenta cv. Ishikawa-wase, amounted to about 10 to $30 \%$ of those in the non-crystalline part (upper part). The decrease in protein content was greater in the storage proteins than in the other soluble proteins, based on the zymograms and densitograms of sodium dodecyl sulfatepolyacrylamide gel electrophoresis (SDS-PAGE). The corms of C. esculenta cv. Calamba in the Philippines looked very similar to cv. Ishikawa-wase in size and outer form, and some of them showed the symptom of crystalline taro. Further, the zymogram of cv. Calamba was the same as that of cv. Ishikawa-wase, and the molecular weights (MWs) of the two storage proteins were also the same, that is, $11-13$ and $23-26 \mathrm{kD}$. The protein content in the corms of Xanthosoma sagittifolium cv. San Fernando was 2 to 3 times higher than that in the Colocasia corms described above. Three kinds of storage-like proteins were present and had MWs of about 11,13 and $23 \mathrm{kD}$. The latter two were presumed to be the same as those in the Colocasia corms. The SDS-PAGE zymograms and densitograms of the proteins from diseased cv. Calamba corms were different from those of healthy corms, in that a decrease in the storage proteins and a simultaneous increase in the other soluble proteins were observed in the diseased tissue. Cassava roots seemed to have four kinds of storage-like proteins with MWs of about 23, 30, 37 and $53 \mathrm{kD}$. When either physiological or microbial deterioration occurred in cassava roots, changes in the metabolism of proteins involving a decrease in the storage-like proteins were observed in the tissue, based on the SDS-PAGE zymograms and densitograms.

As reported previously ${ }^{1 / 2)}$, starch is hardly accumulated in the crystalline part (lower part) of crystalline taro, which occurs of ten in Colocasia esculenta (called $C$. antiquorum in the last paper ${ }^{1)}$ ) cv. Ishikawa-wase. Similarly, proteins were supposed to be present in much smaller amounts in the crystalline part than in the non-crystalline part (upper part). The storage proteins were found to be present in Colocasia corms by Hirai et al. ${ }^{3)-5)}$. Hence, it was assumed that the storage proteins were specially decreased in the lower part of crystalline taro. The corms of C. esculenta cv. Calamba, which are often consumed in the Philippines, are very similar to cv. Ishikawawase in size and outer form. Thus, it was interesting to investigate whether or not crystalline taro occurs in cv. Calamba and to compare the proteinaceous natures of $\mathrm{cv}$. Calamba corms with those of $\mathrm{cv}$. Ishikawa-wase, based on the zymograms of sodium dodecyl sulfatepolyacrylamide gel electrophoresis (SDS-

(Food-Scientific Investigations on So-called Crystalline Taro Occurring in the Child-Corm of an Early-Maturing Colocasia antiquorum Named cv. Ishikawa-wase, Reference 1) 
PAGE). Colocasia corms are sometimes infected by some pathogenic fungi such as Penicillium. Thus, metabolic changes in proteins in Penicillium sp.-infected cv. Calamba corms were examined by SDS-PAGE. Since the corms of Xanthosoma sagittifolium cv. San Fernando and cassava roots, as well as Colocasia corms, are consumed in the Philippines, the proteinaceous natures of the two food materials were investigated. Cassava roots are easily subjected to either physiological or microbial deterioration ${ }^{6}$. . Thus, we considered it worthwhile to also investigate the metabolic alteration of proteins in such injured or diseased cassava roots using SDS-PAGE zymograms. The present paper deals with the subjects mentioned above, that is, the proteinaceous natures of the corms of $C$. esculenta cv. Ishikawa-wase and cv. Calamba in connection with crystalline taro, $X$. sagittifolium cv. San Fernando corms, and cassava roots in relation to injured or diseased tissue.

\section{Materials and Methods}

\section{Materials}

Child-corms of Colocasia esculenta (L.) Schott cv. Ishikawa-wase were provided by Nagoya Seika Co., the Nagoya Central Wholesale Market, Nagoya. These were produced in Kagoshima and Miyazaki prefectures from May to November, 1991. C. esculenta cv. Calamba corms, Xanthosoma sagittiflium Schott cv. San Fernando corms, and cassava (Manihot esculenta Crantz) roots were provided by the University of the Philippines at Los Baños (UPLB) and the Los Baños Market. The corms of some other kinds of $C$. esculenta were large and were used at UPLB. The chemicals used here were in reagent grade.

Morphological observations and preparation of protein samples

The corms of cv. Ishikawa-wase, cv. Calamba and the other $C$. esculenta cultivars were cut longitudinally into halves. When semitransparency was seen at the lower part in the cut surface and the reaction to $\mathrm{I}_{2}-\mathrm{KI}$ solution was negative or weak, the corms were regarded as crystalline taro ${ }^{1}$. The tissues were taken from the lower and upper parts of crystalline taro and healthy (non-crystalline) taro. One $g$ of each tissue was homogenized in the cold for $10 \mathrm{~min}$ in 1.0 to $2.0 \mathrm{ml}$ of $50 \mathrm{mM}$ potassium phosphate buffer, $\mathrm{pH} 7.0$, containing $0.1 \%$ sodium isoascorbate and $20 \%$ glycerol using a mortar and pestle in the presence of small amounts of sea sand. The homogenate was filtered through 2 layers of nylon gauze, and the filtrate was centrifuged at $10000 \times g$ for 10 min. The supernatant solution was used as a protein sample (tissue extract) for electrophoresis and protein determination. During the storage of $\mathrm{cv}$. Calamba corms at $10^{\circ} \mathrm{C}$ for some months, some of them were infected by Penicillium sp. in the lower part. The tissues were taken from the non-infected part adjacent to the fungal-infected part as well as the infected part to prepare the protein samples. The healthy tissues of cv. San Fernando corms and cassava roots were also taken for the protein samples. Cassava roots were subjected to physiological deterioration and microbial deterioration (by Botryodiplodia theobromae ${ }^{67}$ ) during storage at $15^{\circ} \mathrm{C}$ for 1 month. The protein samples were prepared from the undamaged parts adjacent to the parts subjected to physiological deterioration and microbial deterioration.

\section{Protein determination}

Proteins in the tissues of $\mathrm{cv}$. Ishikawa-wase were determined by the Kjeldahl method. Proteins in the tissue extracts (protein samples) were analyzed by Bio-Rad Protein Assay using bovine plasma albumin as the standard.

Sodium dodecyl sulfate-polyacrylamide gel electrophoresis (SDS-PAGE)

The electrophoresis was performed under discontinuous and denaturating conditions in a mini-slab gel unit (Marysol Ind. Co., LTD.) according to LAEMMLI ${ }^{7)}$. The slab, $1 \mathrm{~mm}$ thick, consistd of $5 \mathrm{~cm}$ running gel (10-12.5\% polyacrylamide) and $1 \mathrm{~cm}$ stacking gel $(3.3-4.5 \%$ polyacrylamide) and contained 8 sample wells. Protein samples were denatured before electrophoresis by incubation at $100^{\circ} \mathrm{C}$ for $5 \mathrm{~min}$ in 1 $\%$ SDS containing 5\% 2-mercaptoethanol and $12 \%$ glycerol, and the solutions $(20-40 \mu 1)$ were 
loaded in the wells. The current was $10-15 \mathrm{~mA}$ per slab initially and was then raised to $15-20$ $\mathrm{mA}$ per slab. The separated proteins were stained with Coomasie Brilliant Blue R-250 $\left(0.2 \%\right.$ in isopropanol-AcOH$-\mathrm{H}_{2} \mathrm{O}, 25: 10: 65$, $\mathrm{V} / \mathrm{V} / \mathrm{V}$ ) and destained in $10 \%$ acetic acid. Densitometric analysis of the destained gel was done with a Toyo Digital Densitorol (Model DMU-33 C).

\section{Results and Discussion}

The amounts of proteins and starch in crystalline taro

The previous reports ${ }^{122)}$ showed that in crystalline taro, occurring of ten in the corms of cv. Ishikawa-wase, an early-maturing $C$. esculenta, starch was contained much less in the lower part at the parent side, which appeared semitransparent, than in the upper part at the grandchild side. As indicated in Table 1, the protein content in the lower part was 10 to 30 $\%$ of that in the upper part. However, in healthy taro, the protein content in the lower part was almost the same as that in the upper part. As indicated previousiy ${ }^{8}$, when cooked crystalline taro was masticated, the lower part was tougher or sometimes softer than the upper part. Those results show that crystalline taro is unfavorable from the points of nutrition and palatability. The corms of C. esculenta cv. Calamba in the Philippines looked very similar to $\mathrm{cv}$. Ishikawa-wase in size and outer form, and some of them were negative to $\mathrm{I}_{2}-\mathrm{KI}$

Table 1 Protein content in crystalline taro and healthy taro of $\mathrm{cv}$. Ishikawawase

\begin{tabular}{ccccc}
\hline \hline \multirow{2}{*}{ Parts } & \multicolumn{2}{c}{$\begin{array}{l}\text { Crystalline taro } \\
\mathrm{g} / 100 \mathrm{~g} \text { fr. wt. }\end{array}$} & & \multicolumn{2}{c}{$\begin{array}{c}\text { Healthy taro } \\
\mathrm{g} / 100 \mathrm{~g} \text { fr. wt. }\end{array}$} \\
\cline { 2 - 3 } \cline { 5 - 5 } & (A) & (B) & & (A) \\
\hline Lower & 0.19 & 0.49 & & 1.63 \\
Upper & 1.66 & 1.66 & & 1.78 \\
\hline
\end{tabular}

(A) and (B): The corms from two kinds of batches were assayed.

Lower and Upper: Parts at parent-corm and grandchild-corm sides.
Table 2 Protein content in tissue extracts (protein samples) from taro corms sand casava root

\begin{tabular}{cr}
\hline \hline Corms and root & $\begin{array}{r}\text { Proteins } \\
(\mu \mathrm{g} / \mathrm{m} l)\end{array}$ \\
\hline cv. Ishikawa-wase & \\
Crystalline taro & \\
Lower part & 295 \\
Upper part & 1550 \\
Healthy taro & 1200 \\
cv. Calamba & 1560 \\
cv. San Fernando & 3000 \\
Cassava & 700 \\
\hline
\end{tabular}

Each tissue sample was homogenized in 50 $\mathrm{mM}$ potassium phosphate buffer, $\mathrm{pH} 7.0$, and the homogenate was filtered and centrifuged. The supernatant solution was used as a tissue extract (protein sample) (see the text).

solution in the lower part, indicating the presence of crystalline taro. However, any symptoms of crystalline taro were not observed in some other $C$. esculenta cultivars in the Philippines which produced big corms.

The protein content in tissue extracts (protein samples) from taro corms and cassava roots

In crystalline taro of cv. Ishikawa-wase, the protein content was smaller in the tissue extract (protein sample) from the lower part than from the upper part (Table 2). This showed that the distribution in the amounts of soluble proteins between the lower and upper parts was similar to that in total proteins (Table 1). The content of soluble proteins from the corm of cv. Calamba was at the same level as that from cv. Ishikawa-wase. The content of soluble proteins from $X$. sagittifolium cv. San Fernando corm was about 2 times higher than from cv. Ishikawa-wase corm, while that from cassava root was lower (Table 2).

Zymograms and densitograms of SDSPAGE of proteins

1. Comparison of protein samples from the upper part with those from the lower part of crystalline taro 


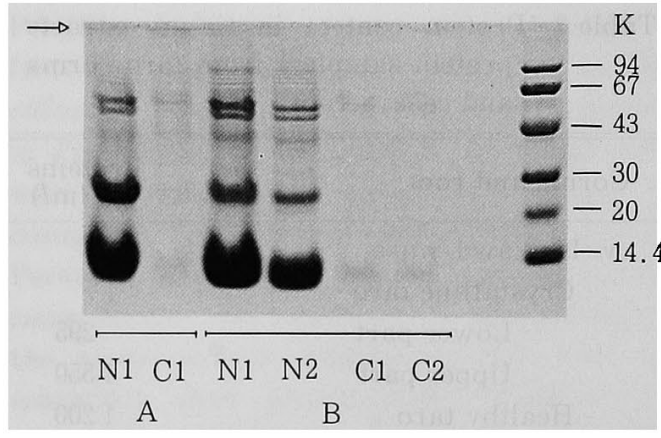

Photo 1 SDS-PAGE-zymograms of protein samples from crystalline taro of cv. Ishkawa-wase

$A$ and B: Two kinds of crystalline taro. The former (marked A) was the same as the protein samples indicated in Table 2.

$\mathrm{N}$ and $\mathrm{C}$ : Protein samples from upper (non-crystalline) and lower (crystalline) parts, respectively.

1 and 2: thirty and $20 \mu \mathrm{l}$ of protein samples were applied, respectively.

$\rightarrow$ : Starting line of running gel.

As indicated in the zymogram (Photo 1), the protein bands in the upper part were strongly stained, but those in the lower part were only weakly stained. This is in accord with the data for the protein content as shown above (Tables 1 and 2). The bands of the two storage proteins (MW, $11-13 \mathrm{kD}$ and $23-26 \mathrm{kD}$, after SDS-mercaptoethanol treatment) appeared in both parts, as formally found by HIRAI et al. ${ }^{3)-5)}$. The densitograms (Fig. 1) showed that the concentrations of the storage proteins (marked 4 and 5) were very high compared with other soluble proteins (marked 1, 2 and 3) in the upper part. However, in the lower part, the intensity showed almost no difference between the storage proteins and the other soluble proteins. This suggests that in crystalline taro, the amino acids transported from the leaves and stems are in insufficient amounts and are transported to the grandchild corm and the upper part through the lower part but are not accumulated in the lower part.

2. Comparison between the corms of $\mathrm{cv}$. Calamba and cv. Ishikawa-wase

As seen in Photo 2, the pattern of $\mathrm{cv}$.

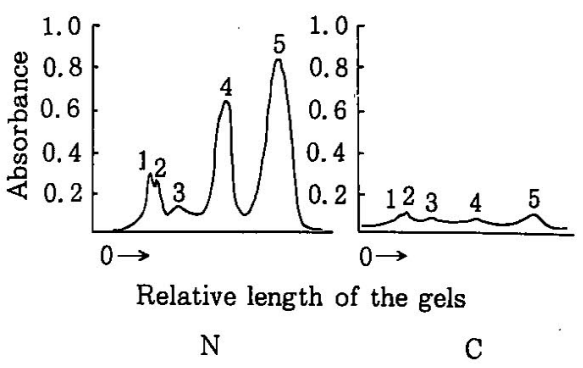

Fig. 1 Densitograms of protein samples from crystalline taro of cv. Ishikawa-wase

$\mathrm{N}$ and $\mathrm{C}$ : Protein samples from upper (non-crystalline) and lower (crystalline) parts, respectively.

Peaks marked 4 and 5, and peaks marked $1,2,3$ : The storage proteins and the other soluble proteins, respectively.

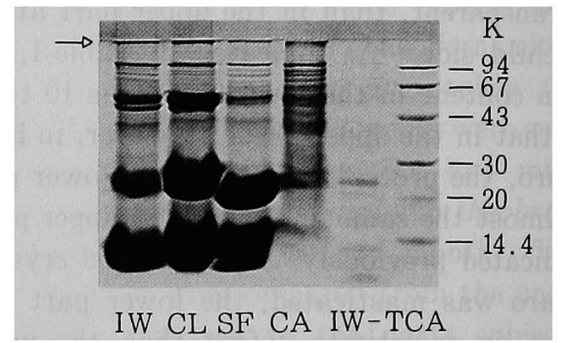

Photo 2 SDS-PAGE zymograms of protein samples from various tuberous materials

IW, CL, SF, and CA : cv. Ishikawa-wase, cv. Calamba, cv. San Fernando and cassava.

IW-TCA: A protein samples from cv. Ishikawa-wase corm was precipitated by trichloroacetic acid (TCA) solution, the precipitate was solubilized by the buffer, and the solution was subjected to SDSPAGE. The zymogram indicated that TCA-treatment caused partial hydrolysis.

$\rightarrow$ : Starting line of running gel.

Calamba corm was practically the same as that of cv. Ishikawa-wase corm. Further, their densitograms coincided. As mentioned above, crystalline taro sometimes occurred in the corms of both cultivars. They say that $C$. esculenta in Japan came from the Southeast Asian regions. Thus, it is very possible that 
cv. Calamba in the Philippines is a relatively close cultivar to $\mathrm{cv}$. Ishikawa-wase. To solve that, we shall have to investigate the nativePAGE patterns and growing characteristics as fasciculation of both cultivars, as reported by Hirai et al. ${ }^{3 \text { ). }}$

3. Comparison of the zymograms of cv. San Fernando corm and cassava root with that of Ishikawa-wase

Photo 2 showed that the zymogram of $X$. sagittifolium cv. San Fernando was similar to that of cv. Ishikawa-wase, and three main proteins with $\mathrm{MWs}$ around 11,13 and $23 \mathrm{kD}$, possibly the storage proteins, were present in the zymogram. It is very likely that the latter two proteins are the same as the storage proteins of $\mathrm{cv}$. Ishikawa-wase (cf. Photo 1). With respect to the zymogram of cassava (Photo 2), the main proteins were composed of four components, whose MWs were about 23, 30,37 and $53 \mathrm{kD}$. The above results were also indicated by the densitograms (cf. Fig. 3). We assumed that the proteins were the storage proteins, for the reason given in the next section, 4 .

4. Changes in protein metabolism in injured

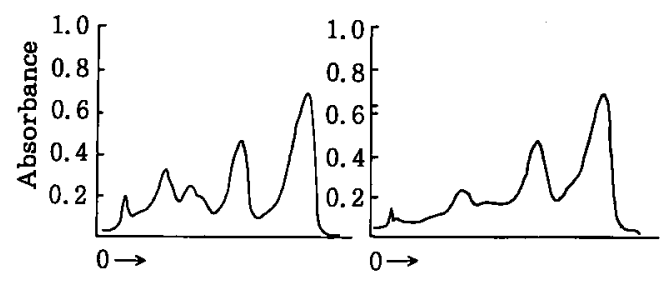

Relative length of the gels

Diseased

Infected

Fig. 2 Densitograms of protein samples from diseased and infected tissues of cv. Calamba

Diseased and Infected: Protein samples from the non-infected part adjacent to the infected part, and from the infected part, respectively. The densitogram from healthy tissue was principally the same as that from the upper part of crystalline taro of cv, Ishikawa-wase (see Fig. 1), hence, did not show that here.

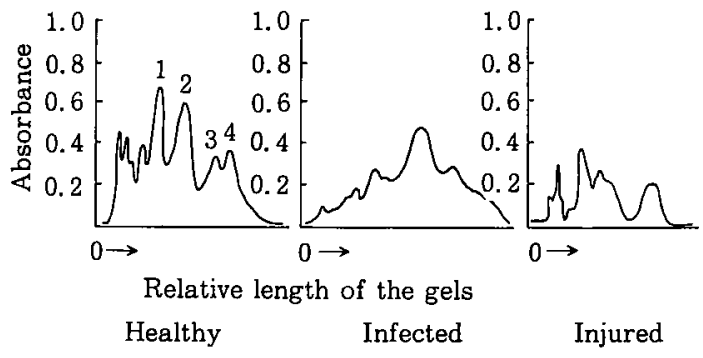

Fig. 3 Densitograms of protein samples from healthy, infected, and injured tissues of cassava

Healthy, Infected, and Injured: Protein samples from healthy tissue and from the non-damaged parts adjacent to the parts subjected to microbial deterioration (MD) and physiological deterioration (PD), respectively. Peaks marked, 1, 2, 3 and 4 in the case of healthy tissue were assumed to be the storage protein.

or diseased tissues

The densitograms of the protein samples from the non-infected part adjacent to the Penicillium-infected part and the infected part of cv. Calamba were different from that of the healthy corm (Fig. 2, cf. Fig. 1 also). That is, the proteins of MWs 13 and $23 \mathrm{kD}$ were decreased, but the other soluble proteins were increased. Thus, the above data presented further evidence that the above two proteins were the storage proteins, in addition to the report of HiraI 'et al. ${ }^{3)}$ which showed that the two were present in the corms but not in other organs. Cassava roots are easily subjected to physiological deterioration (PD) and microbial deterioration (MD). The densitograms of the protein samples from undamaged parts adjacent to the PD- and MD-exposed parts were different from that from the healthy root (Fig. 3). The four storage-like proteins mentioned above were decreased, and the other soluble proteins were increased. Hence, the former proteins were regarded as the storage proteins.

Acknowledgement : We express our thanks to Dr. T. HiraI, National Research Institute of Vegetables, Ornamental Plants and Tea for showing us his ongoing research on the storage 
proteins of $C$. esculenta corms. We are indebted to Professor H. TAkahashi, Nagoya Women's University, for instructing us in the method of SDS-PAGE. We are grateful to Ms. L. R. Laureles, Ms. H. C. Maghirang and Mr. N. Borbor, Institute of Food Science and Technology, the University of the Philippines at Los Baños for assisting us in getting the corms and roots for the research. Thanks are also given to the Philippine Root Crops Research and Training Center, Visayas State College of Agriculture, Baybay, Leyte for providing us with the large corms produced by some C. esculenta cultivars.

\section{References}

1) Uritani, I. and Takeuchi, W.: Nippon Shokuhin kogyo gakkaishi, 37, 306 (1990).

2) Ono, T. and Takeda, H.: Agric. Hortic., 63, 1339 (1988) (In Japanese).

3) Hirai, M., Sato, T. and Takayanagi, K. : Japan. J. Breed., 39, 307 (1989).

4) Hirai, M., Nakamura, K. and Sato, T. : Japan. J. Breed., 40, Separate Issue No. 2, $142(1990)$.

5) Hirai, M., Nakamura, K. and Sato, T. : Japan. J. Breed., 42, Separate Issue No. 1, 220 (1992).

6) URitani, I., Data, E.S. and Tanaka, Y. : Tropical Root Crops-Postharvest Physiology and Processing (URITANI, I. and Reyes, E.D. Eds.), Jpn. Sci. Soc. Press, Tokyo, 61, 1984.
7) Laemmli, U.K., Nature, 227, 680 (1970).

8) Uritani, I., Fukuta, K., Mori, R. and Yamada, N.: Abstracts of Ann. Meeting of Jpn. Soc. Food Sci. Tech., p. 130, Hiroshima (1991).

(Received Mar. 24, 1992)

\section{サトイモ塊茎及びキャッサバ根における} 蛋白質の性質

瓜谷郁三* - 竹内若子* - 小島禎子* - 佐々不美帆 内藤修子* ・永田和子* ・ バーヒリオ・V・ガルシア゙*

*名古屋女子大学家政学部

（干467 名古屋市瑞穗区汐路町 3-40)

**フィリピン大学ロスバニヨス校食品科学工学研究所 (干4031 フィリピン国ラグナ州カリジ町)

サトイモ（Colocasia）石川早生品種にみられる水 晶芋において, 水晶部の蛋白質量は非水晶部の 10 30 \% 程であり, SDS 電気泳動からみて，その減少は特に 貯蔵蛋白質（2 種類）に顕著にみられた。フフリピン産 のカランバ品種は外見的に石川早生品種に酷似し，その 塊䔄中には水晶㧘が見いだされ，更に電気泳動図も一致 していた. Xanthosoma 属のサンフェルナンド品種に おける蛋白質含量は石川早生品種よりも多く，電気泳動 図は似ていたが，眝蔵様蛋白質は 3 種類存在していた。 カランバ品種が病害を受けると，貯蔵蛋白質は隇少し， 他の可溶性蛋白質の増加がみられた。 キャッサバ根には 貯蔵様蛋白質が 4 種類存在し, 生理的変質や微生物的変 質を受けると，それらの成分の減少がみられるなど，蛋 白質代謝は激しく変動した。 